Article

\title{
Social Media, Students, and the Law
}

\author{
Martha McCarthy
}

check for

updates

Citation: McCarthy, Martha. 2021. Social Media, Students, and the Law. Laws 10: 81. https://doi.org/ 10.3390/laws10040081

Received: 13 September 2021

Accepted: 26 October 2021

Published: 31 October 2021

Publisher's Note: MDPI stays neutral with regard to jurisdictional claims in published maps and institutional affiliations.

Copyright: (C) 2021 by the author. Licensee MDPI, Basel, Switzerland. This article is an open access article distributed under the terms and conditions of the Creative Commons Attribution (CC BY) license (https:/ / creativecommons.org/licenses/by/ $4.0 /)$.
Department of Educational Leadership and Administration, Loyola Marymount University, Los Angeles, CA 90045, USA; martha.mccarthy@lmu.edu

\begin{abstract}
Escalating social media use has become a worldwide phenomenon, with easier access each day. Teenagers seem particularly likely to use these expanding platforms. This article focuses on one aspect of social media developments—the school's ability to intervene to curtail the harmful impact of cyberbullying on students. After presenting data on social media use and the scope of cyberbullying, it addresses the authority of school personnel to discipline students for harmful internet expression initiated off school grounds, including threats, harassment, and bullying. The Supreme Court's decision in Mahanoy Area School District v. B.L. (2021) is addressed in detail as it is the high court's first ruling in a case involving student off-campus expression. This article concludes with a discussion of legal guidance that is currently available and provides suggestions for school personnel in their efforts to curtail cyberbullying and create a positive school environment. Given the Supreme Court's ambiguity as to when students can be disciplined for their off-campus speech, school personnel need strategies to prevent hurtful student expression before it takes place, thus avoiding pain to victims and perpetrators. Education is our greatest resource to combat the escalating cyberbullying that is plaguing American youth.
\end{abstract}

Keywords: student expression; social media; First Amendment; cyberbullying

Social media has changed the way we live our lives. From the way we get our news to the way we interact with our loved ones, social media is everywhere. It's unavoidable, it's powerful and it's here to stay. (Mohsin 2021, p. 1)

Escalating social media use has become a worldwide phenomenon. The platforms are continually expanding, which makes access easier each day. Teenagers seem particularly likely to use social media to communicate with peers and others.

This article focuses on one aspect of social media developments-the school's ability to intervene to curtail the harmful impact of cyberbullying on students. After presenting data on social media use and the scope of cyberbullying, it addresses the authority of school personnel to discipline students for harmful expression initiated off school grounds via the internet, including threats, harassment, and bullying. The U.S. Supreme Court's decision in Mahanoy Area School District v. B.L. (2021) is addressed in some detail, as it is the high court's first ruling in a case involving student off-campus expression. This article concludes with a discussion of available legal guidance and provides suggestions for school personnel in their efforts to curtail cyberbullying and other harmful online student expression in order to create a positive school environment conducive to learning.

\section{Social Media Use}

As of January 2021, more than half the world's population (53.6\%, 4.6 billion people) used social media (Chaffey 2021). The average daily social media use in 2020 was almost two and one-half hours, up from one and one-half hours in 2012 (Statista 2021a). Approximately seven in ten Americans use at least one social media platform (Auxier and Anderson 2021). In 2021, the number of internet users varied greatly around the world, from $8 \%$ of the population in middle Africa to $74 \%$ in North America and $79 \%$ in Northern and Western Europe (Chaffey 2021). 
While social media use is increasing in general, this is especially true for teenagers. A Manhattan College survey of adolescents in 2015 reported that teens spent an average of 3 $\mathrm{h}$ a day on electronic devices other than for school work and that approximately two-thirds of the respondents used two or more social media platforms (Mendez-Baldwin et al. 2015). Almost all (95\%) of teens in the U.S. spend some time online using social media (Hinduja and Patchin 2014). Children today feel continually connected to each other, as the conversations on social media never end.

Every technological development has pros and cons. Social media can be positive in connecting youth with family members and peers. Social media can provide a link to keep up with the daily activities of relatives and friends who may live far away. Additionally, some individuals can find connections in social networks that may not be available in traditional face-to-face relationships (Dhir 2016).

However, when communication is primarily via electronics, meanings are often not clear. Moreover, making true friendships is more difficult via social media than through personal contacts. Words communicated online and without "the interpretive aid of body language are easily misconstrued" (People of Colorado 2020, p. 730). Teens miss the impact of their expression on others because the electronic communication is not happening in real time, and it occurs without gestures and voice inflections, which are present in face-to-face interactions (Ehmke 2020). Social media can encourage children to be more assertive in voicing their opinions in ways that may threaten relationships. When most communication takes place looking at a screen, this not only leads to misinterpretations, but also makes the senders feel anonymous in expressing what may be very hurtful opinions. Data are not yet available on the long-term effects of this dramatic change in manner of communication.

\section{Escalation of Cyberbullying}

Cyberbullying, also referred to as online bullying, is defined as bullying that takes place through electronic means and is willful, "repeated, unwanted or aggressive, and includes a real or perceived power imbalance" that can be physical, mental, or social (Paradigm Treatment 2018, p. 1). Cyberbullying may appear as harmful posts on various social media platforms, mean comments while engaged in gaming, or specific web sites intended to threaten or embarrass the victims (see Hinduja and Patchin 2013, 2014).

Almost two-thirds of the students in a 2018 study identified online bullying or harassment as a major problem (Anderson 2018). The most common tools used to cyberbully peers are Facebook, Snapchat, Instagram, Twitter, YouTube, Whatsapp, Tiktok, and Pinterest (Robinson 2021; Statista 2021b). However, any online platform can be used, and new platforms are continually emerging. A 2015 survey of cyberbullying among adolescents found a significant relationship between the number of social media networks used and the amount of cyberbullying experienced (Mendez-Baldwin et al. 2015). More than two-fifths of teens report that they are online almost constantly, and there is a correlation between time online and the likelihood of being bullied (Anderson 2018). Samar Hinduja (2021, p. 4) has asserted that the "increasingly vicious, targeted mudslinging across social media between political candidates ... has arguably normalized similar conduct among youth and adults alike".

Recently, some gaming cyberbullying includes "swatting"; perpetrators make false criminal complaints to police who "send a swat team" in response (Cook 2021, p. 23). Additionally, as students become increasingly technologically sophisticated, we may see more efforts by cyberbullies to take over victims' social media accounts or even interfere with school databases. For example, in a California case currently in progress, the victim and her family are alleging that a student retaliated for the victim's refusal to go out with him by taking over her Instagram account, hacking into her family's computer, sending death threats, and ultimately hacking into the school's student information system and lowering her grades. The suit alleges that the software company and the school did not take sufficient action to protect the student's personal information (Council of School Attorneys 2021). 
Bullying among children certainly has a lengthy history, but not until the 1970s did researchers seriously study the psychological effects of bullying (see Koo 2007). Those bullied are more prone to mental health issues, such as low self-esteem, social isolation, academic difficulties, and problems in forming healthy family and peer relationships (Hinduja and Patchin 2014; Mendez-Baldwin et al. 2015), and a 2013 study reported that cyberbullying can have greater negative effects than traditional bullying (Bauman and Newman 2013). Victims can develop severe symptoms of anxiety and depression that can lead to suicide or other self-harm, such as cutting (Mendez-Baldwin et al. 2015; Tsilimparis 2019). Suicides increased $57.4 \%$ among those aged ten to twenty-four from 2007 to 2018; and in 2020, suicide was the second leading cause of death among U.S. teenagers (Cook 2021).

Marginalized students, such as lesbian, gay, bisexual, transgender, and questioning (LGBTQ) individuals, shy and socially awkward students, those who are overweight, and those from low-income families are far more likely to be the victims of cyberbullying (Cook 2021; Kosciw et al. 2020). Sexual minority and gender-nonconforming peers are more often targeted by boys than by girls (Reigeluth and Addis 2016). However, a 2015 study documented that in general, female students are more likely to become cyberbullies or victims (Mendez-Baldwin et al. 2015).

Cyberbullying among students nearly doubled between 2007 and 2016 (Tsilimparis 2019). The Cyberbullying Research Center reported in a 2018 study that nearly $60 \%$ of U.S. teens had been cyberbullied or had bullied others online (Anderson 2018). Among 28 countries studied in 2018, the United States was third in terms of the percentage of parents reporting that their children were cyberbullied (Cook 2021). The most common types of cyberbullying were: "offensive name calling $(42 \%)$; spreading false rumors (32\%); receiving explicit images they did not ask for (25\%); constant asking of who they are, what they are doing, and who they are with ... (21\%); physical threats (16\%); [and] having explicit images shared without their consent (7\%)" (Cook 2021, p. 8). Girls were more likely than boys to say that false rumors had been spread about them and to say they had received explicit images not requested.

Acceptance by peers is important for adolescents, and a popular cyberbullying strategy is to post polls about particular classmates. Seeing polling data on how well they are liked can be devastating to teens (Dhir 2016). Girls seem especially vulnerable to risks of relational aggression based on insecurities (Ehmke 2020).

A big danger with children communicating electronically is that it is much easier for individuals to be cruel than when communicating in person. If a child says something very hurtful in person and sees tears in the recipient's eyes, the bully may back off. However, machines put a buffer between the sender and receiver. "Impulse checks are in short supply when things are virtual" (Hess 2021). Moreover, if children are confronted by a playground bully, they can go home and get away from the bully. However, there is no escaping the cyberbully (Goodno 2011). A wide audience can view the online attacks, unlike the small group that is present during schoolyard bullying.

\section{The School's Legal Authority Pertaining to Off-Campus Student Expression}

Schools have little ability to limit students' social media use or their engagement in cyberbullying away from school grounds. However, they may be able to punish the perpetrators under certain circumstances. Courts have recognized that certain types of expression are "not assured constitutional protection" (McCarthy et al. 2019, p. 109). For example, true threats are not constitutionally protected and thus can be the basis for school disciplinary action and perhaps criminal prosecution. In addition, school personnel have an obligation to respond to harassment complaints, as the victims can seek damages from school districts for peer expression considered harassment under federal civil rights laws. Also, all states have antibullying laws, most of which authorize schools to impose sanctions for cyberbullying, and the U.S. Supreme Court recently recognized that school personnel can discipline students for off-campus expression that is considered "serious or severe 
bullying" (Mahanoy Area School District v. B.L. 2021, p. 2045). Each of these topics is discussed below.

\subsection{Student Threats}

True threats are not protected by the First Amendment for children or for adults. Recognizing that social media complicates identifying true threats, the Colorado Supreme Court clarified "that the protection of free speech does not vary by medium of expression" (People of Colorado 2020, p. 726). It defined a true threat as "a statement that ... an intended or foreseeable recipient would reasonably perceive as a serious expression of intent to commit an act of unlawful violence," considering "the totality of the circumstances" (p. 721). In determining if a true threat has been made, courts consider a number of factors, such as the reactions of the recipient and other listeners, whether the utterance is communicated to the victim; whether similar statements have been made to the victim previously; and whether the victim had reason to believe that the speaker would engage in violence (see United States v. Dinwiddie 1996; Virginia v. Black 2003). Additional considerations might include "the statement's role in a broader exchange, if any ...; the medium or platform through which the statement was communicated ... ; [and] the manner in which the statement was conveyed (e.g., anonymously or not ... )" (People of Colorado 2020, p. 731).

In the school context involving internet expression, several courts have found true threats initiated by students, even though some courts also may have concluded that the expression was not protected, applying the exceptions to constitutional protection announced in Tinker v. Des Moines Independent School District (1969). In its landmark Tinker decision, the Supreme Court declared that student expression posing a disruption of the educational program or interfering with the rights of others is not protected by the First Amendment. For example, in 2011, the Eighth Circuit found a true threat in a student's online message sent from home to a classmate in which he mentioned getting a gun and shooting other students at school. The appeals court reasoned that school authorities did not have to wait for the threat to be carried out to discipline the student (D.J.M. v. Hannibal Public School District 2011).

Additionally, a California student was charged with attempting a criminal threat after he posted a photograph to his phone depicting a realistic replica of a gun with the caption indicating that he would take it to school the next day (In re A.G. 2020). There was sufficient evidence that the photograph would be understood as a threat and that the student willfully expressed his intent to cause great harm, which constituted making a criminal threat. A Florida court similarly found a picture sent by a student on Snapchat of a scoped AR-15 rifle with the caption that it was for "show and tell" on Monday was sufficient to cause a reasonable person to be alarmed and thus was considered a threat to kill or do bodily injury (Florida v. Cowart 2020). Several students voiced that they were concerned for their safety after seeing the picture.

However, a Pennsylvania commonwealth court ruled in favor of a student accused of making terroristic threats and engaging in cyberbullying against a classmate. The court concluded from the evidence about the memes (videos with superimposed captions) posted on Snapchat that neither allegation was sufficiently supported to justify the student's expulsion. The student asserted that the statements about shooting up the school were made in jest (J.S. v. Manheim Township School District 2020).

Of course, school authorities can discipline students for inflammatory expression that is not considered a true threat or fighting words (see, e.g., LaVine v. Blaine School District 2001). For example, the Second Circuit in Wisniewski v. Weedsport Central School District (2007) held that a student's off-campus posting of an icon depicting killing his teacher, although not considered a true threat, would reasonably cause a school disruption under Tinker. Additionally, the Ninth Circuit upheld disciplinary action against a student who sent instant messages from his home to friends bragging about his weapons and threatening to shoot specific classmates. This court might have found the expression to be 
a true threat, but instead it applied both of Tinker's exceptions to constitutional protection, finding that the expression posed a disruption of the school and interference with the rights of others (Wynar v. Douglas County School District 2013).

\subsection{Peer Harassment under Federal Civil Rights Laws}

Student expression does not have to represent a true threat to evoke school consequences. Student harassment can abridge federal laws, whereas bullying (discussed below) can abridge state laws. Although the terms bullying and harassment are often used interchangeably, even in state laws and federal guidance documents (see, e.g., United States Department of Education, Office for Civil Rights 2014), there are differences from a legal standpoint. Federal civil rights laws provide remedies in the form of damages for behavior that meets their definition of harassment, whereas damages are not available under state antibullying laws; definitions of bullying vary somewhat across state laws and school board policies pursuant to these laws.

Behavior considered to be harassment can result in liability for the education institution under certain circumstances. Thus, schools subject to civil rights laws must have procedures in place for victims to report alleged harassment, and they must follow up on the complaints to document that they were responsive to the victims. Liability can be assessed against educational institutions under Title IX of the Education Amendments of 1972 for sexual harassment, Title VI of the Civil Rights Act of 1964 for harassment based on race or ethnicity, and Title II of the Americans with Disabilities Act of 1990 for harassment based on disabilities.

Victims have a high bar to establish unlawful peer harassment that would result in monetary liability under these federal civil rights laws. They must establish that school personnel with authority to curtail the harassment were aware of it and reflected deliberate indifference toward the victim, which is the standard for employee-to-student harassment as well (see Gebser v. Lago Vista Independent School District 1998). In addition to satisfying these two criteria, a successful claim of peer harassment must also establish that the harassment was so severe, persistent, and objectively offensive that it interfered with the victim's ability to benefit from the educational program (Davis v. Monroe County Board of Education 1999). This standard is difficult to meet, so most courts have ruled in favor of school districts in peer harassment cases. For example, the Eighth Circuit held that the school did not reflect deliberate indifference to a report of a fellow student's upper arm touching the victim's breast during a kickball game, which allegedly led to a second incident, so the Title IX claim was rejected. The court further reasoned that even if school personnel were deliberately indifferent, the alleged harassment did not meet the standard of being so severe, pervasive, and objectively offensive that it would have deprived the victim of access to educational opportunities (Doe v. Dardanelle School District 2019).

However, the Supreme Court's standard is not impossible to satisfy. To illustrate, in a Rhode Island case, a student was able to establish that the peer harassment she suffered was sufficiently severe and pervasive to create Title IX liability and that school officials failed to respond appropriately to her alleged rape, which made her more vulnerable to subsequent peer harassment (Doe v. Pawtucket School Department 2020). In an earlier case, the Second Circuit concluded that allegations of racial harassment were severe, pervasive, and objectively offensive and that the jury reasonably found that the school district actually knew of the continuing racial harassment and was deliberately indifferent. Damages of $\$ 1$ million were granted to the victim for the school district's violation of Title VI (Zeno v. Pine Plains Central School District 2012). Additionally, a New Jersey superior court ruled in favor of the student victim in connection with severe and persistent sexual orientation peer harassment, reasoning that school authorities did not take effective action to stop the harassment (L.Q. v. Toms River Regional Schools Board of Education 2005). 


\subsection{State Antibullying Laws}

All states have laws that prohibit schoolchildren from engaging in bullying activities. Montana was the last state to enact an antibullying law in 2015. These state laws (except Montana's) require school districts to adopt antibullying policies, and all but a handful include school sanctions against students who engage in bullying (United States Department of Health and Human Services 2019).

Most of the state antibullying laws incorporate the Tinker exception to constitutional protection of student expression in terms of whether the expression poses a disruption of the educational process, and many include Tinker's second exception for expression that interferes with the rights of others. The Massachusetts antibullying law is typical in defining bullying as:

the repeated use by one or more students or school staff members ... of a written, verbal, or electronic expression, or a physical act or gesture or any combination thereof, directed at a victim that: [i]causes emotional or physical harm to the victim or damage to the victim's property; [ii] places the victim in reasonable fear of harm to himself or of damage to his property; [iii] creates a hostile environment at school for the victim; [iv] infringes on the rights of the victim at school; or [v] materially and substantially disrupts the education process of the orderly operation of a school. For the purposes of this section, bullying shall include cyberbullying. (Massachusetts General Laws chp. $71 \S \S 37 \mathrm{O} 2020$ )

Pennsylvania's law also authorizes schools to address bullying initiated off campus if the acts are directed at other students; are severe, persistent or pervasive; and substantially interfere with a student's education, create a threatening environment, or substantially disrupt the school's orderly operation (24 Pennsylvania Statutes §13-1303.1-A 2020). The law requires each Pennsylvania school to adopt a policy that specifies disciplinary consequences for bullying and may provide for prevention and education programs.

As noted, the state laws usually charge school districts with adopting more specific antibullying policies. For example, the Hopkinton school district's policy pursuant to Massachusetts law defines the aggressor as someone "who engages in behavior defined as bullying, cyberbullying or retaliation in the state law" (Doe v. Hopkinton Public Schools 2020, p. 456). Cyberbullying is additionally defined in the district as "bullying through the use of technology or any electronic communication which shall include, but shall not be limited to, any transfer of signs, signals, writing, images, sounds, data or intelligence of any nature transmitted ... by ... cellphones, electronic mail, internet communications, instant messages or facsimile communication" (p. 456). The policy includes training and support for targets as well as for perpetrators, who are subject to the school district's student disciplinary policies.

To date, most courts have not questioned states' and school districts' ability to enact antibullying laws and district policies that include penalties for cyberbullies. For example, the federal district court rejected claims that the Massachusetts law was vague and overbroad (Doe v. Hopkinton Public Schools 2020). However, in 2014, the New York high court found a county's law to be overbroad (People v. Marquan M. 2014). The law was used to punish a high school student who anonymously posted sexual information about classmates on a public website. New York had previously enacted the Dignity for All Students Act in 2010 (New York Education Law $\S 10$ 2020), which imposed school penalties for bullying at school and school events, and it amended the law in 2012 to cover bullying by electronic communication where it would foreseeably create a risk of a substantial school disruption (New York Education Law § 11[8] 2020). The act did not criminalize bullying behavior but incorporated educational penalties, including suspension from school. Before the state law was amended to address cyberbullying, Albany County enacted a new law in 2010 making cyberbullying a misdemeanor and imposing up to a year in jail and a $\$ 1000$ fine for cyberbullying directed toward minors. The New York high court found that the criminal law was vague and overbroad in covering some protected speech (People v. Marquan M. 2014). Possibly, under the Supreme Court's ruling discussed below, several state laws 
also may be vulnerable to First Amendment challenges by imposing penalties for some expression that may be constitutionally protected.

\subsection{The Supreme Court and Student Off-Campus Expression}

In 2017, a 14-year-old high school student was disappointed about being placed on the junior varsity cheerleading squad for a second year instead of being elevated to the varsity squad. She was also frustrated with her position on a private softball team, and on the weekend at a local store she vented her frustration through two snapchat posts, one of which said " $\mathrm{f}^{* *} \mathrm{k}$ cheer, $\mathrm{f}^{* *} \mathrm{k}$ softball, $\mathrm{f}^{* *} \mathrm{k}$ school, $\mathrm{f}^{* *} \mathrm{k}$ everything." A fellow cheerleader took a screen shot of the post and other members of the squad were upset and shared the profane post with the coaches. Reasoning that B.L.'s post violated the squad's and school's rules she had agreed to respect, the coaches suspended B.L. from the squad for the year. The rules, which she signed, required among other things for cheerleaders to "have respect for your school, coaches, teachers, other cheerleaders and teams," and specified that "there will be no toleration of any negative information regarding cheerleading, cheerleaders, or coaches placed on the internet'" (Mahanoy 2020, p. 193).

After B.L. and her parents were unsuccessful in all levels of school appeals, they sought a judicial injunction to allow her to participate on the squad, which the federal district court granted. The federal district court then ruled in favor of B.L., reasoning that her expression did not threaten a school disruption under the standard articulated in Tinker v. Des Moines (1969).

The Third Circuit affirmed the federal district court's decision but with different reasoning. The appellate court's decision in favor of B.L. would have attracted little attention if the court had not made two sweeping proclamations. Unlike five other federal appellate courts (see Holden 2018; McCarthy 2021), the Third Circuit ruled that Tinker does not apply to student expression initiated off school grounds, which is subject to the same First Amendment protections afforded to "speech by citizens in the community at large" (Mahanoy 2020, p. 189). The appeals court also declared that students do not waive their First Amendment rights as a condition of extracurricular participation. While recognizing that rights can be knowingly waived, the Third Circuit concluded that B.L. did not relinquish her free expression rights at issue by signing a statement that she would not convey detrimental information about the school on the internet, since she was simply venting her frustration rather than sharing "matters of fact" (p. 189).

The Supreme Court ruled eight-to-one in favor of B.L., finding that the school district violated her First Amendment rights (Mahanoy 2021). However, the Court did not affirm the Third Circuit's reasoning, concluding instead that the special characteristics of the school would allow it to regulate some student expression initiated off campus, including "serious and severe bullying or harassment targeting particular individuals, threats aimed at teachers or other students, the failure to follow rules concerning ... online school activities, and breaches of school security devices" (Mahanoy 2021, p. 2045). Although not specifying what expression falls within each of these categories, the Court found that B.L.'s expression did not and posed no significant disruption to the school or the cheerleading program.

The Court acknowledged that Tinker's exceptions to constitutional protection can apply away from campus under certain circumstances, but it was not precise as to when the school's interest in regulating such off-campus speech is diminished. It noted that schools rarely function in place of parents (in loco parentis) off campus; courts should be "more skeptical of a school's efforts to regulate off-campus speech" so students are not subject to school monitoring around the clock; and schools should protect unpopular expression, especially when initiated away from school (Mahanoy 2021, p. 2046). However, the Court was vague as to specific off-campus expression that would be protected and left "for future cases to decide where, when, and how ... the speaker's off-campus location will make the critical difference" (p. 2046). 
The Court also did not address the Third Circuit's conclusion that students do not waive their First Amendment rights by participation in extracurricular activities. Thus, it did not reiterate what many lower courts have held in terms of extracurricular participation being a privilege, which can include conditions that cannot be attached to school attendance (see, e.g., Doninger v. Niehoff 2011; Lowery v. Euverard 2007; Wildman v. Marshalltown 2001).

Justice Alito, joined by Justice Gorsuch, concurred in the Court's judgment but wrote separately to emphasize that off-campus expression deserves more protection because parents have the primary authority to regulate their children's speech away from school. They recognized that "the most difficult category" of student off-campus expression involves harmful comments directed toward classmates, which are "not easy to define with precision" in terms of appropriate school sanctions for such bullying (Mahanoy 2021, p. 2057). Justice Thomas dissented, arguing that the school district's disciplinary action against B.L. for her profane post should have been upheld (Mahanoy 2021, p. 2059).

\section{Future Directions}

The Mahanoy decision was the first Supreme Court ruling in fifty years upholding the student speaker, as the other three Supreme Court post-Tinker decisions narrowed the application of the landmark decision. In Bethel School District v. Fraser (1986), the Court held that schools could discipline students for lewd and vulgar expression without evidence of a disruption. Two years later in Hazelwood School District v. Kuhlmeier (1988), the Court made a distinction between school-sponsored and personal student expression, holding that student expression viewed as representing the school can be censored for pedagogical reasons. More recently, in Morse v. Frederick (2007), the Court held that students can be punished for expression that promotes illegal drug use. The Supreme Court in Mahanoy did not establish additional restrictions in applying Tinker, indicating that public schools should exhibit caution in punishing students for expression initiated away from campus. Unfortunately, the Court was not clear as to what specific off-campus expression can be the basis for disciplinary action. The discussion below focuses on the legal guidance that is available and explores other strategies that school personnel can employ in their efforts to curtail cyberbullying.

\subsection{Legal Guidance}

Public school personnel should be relieved that the Supreme Court specifically found "serious and severe" cyberbullying to be one type of student off-campus expression that can be the basis for schools to punish the perpetrators (Mahanoy 2021, p. 2045), even though the Court did not offer assistance in identifying what speech specifically belongs in this category. Moreover, the Court said that public schools have "a heavy burden" in justifying restrictions on "political or religious speech that occurs outside school" (Mahanoy 2021, p. 2046). Thus, might a student post hateful comments about LGBTQ classmates, contending that the posts are grounded in religious beliefs, and thus should be considered protected expression? The Court did not address this and other significant issues. Despite the Supreme Court's ambiguity in Mahanoy, this ruling appears to leave states' antibullying laws that address cyberbullying intact for now.

Perhaps some guidance can be gleaned from federal appellate decisions, which the Supreme Court has declined to review. Indeed, B.L.'s internet expression was far more tepid and less detrimental to the school community than the expression in several of the cases the high court has refused to hear since 2011. For example, the Fourth Circuit upheld the suspension of a student who created a website that ridiculed a classmate with allegations that she was a slut with herpes (Kowalski v. Berkeley County Schools 2011). The appeals court agreed with the school that the student speaker had created a hate website in violation of the school's policy forbidding "harassment, bullying, and intimidation" (574). Finding a strong connection between the student's website and the school environment, the appeals court applied the Tinker exceptions to constitutional protection, reasoning that 
school personnel are justified in disciplining students' off-campus speech that "materially and substantially interferes with the requirements of appropriate discipline in the operation of the school and collides with the rights of others" (Kowalski v. Berkeley County Schools 2011, p. 572).

Subsequently, the Fifth Circuit upheld a school's disciplining of a student who posted a vulgar and profane rap on YouTube and Facebook (Bell v. Itawamba County School District 2015). The appeals court found the rap to harass and threaten two coaches for their alleged indiscretions in connection with female students. In upholding the student's temporary suspension and his placement in an alternative education program for six weeks, the appeals court applied Tinker. It concluded that the student's rap posed a substantial disruption of the school and was intended to reach a wide audience and to intimidate school staff members.

Three years earlier, the Eighth Circuit upheld the suspension of students for creating a racist and sexist website and blog, reasoning that the lower court should not have enjoined the school's disciplinary action (S.J.W. v. Lee's Summit R-7 School District 2012). The appeals court found it to be reasonably foreseeable that the blog would reach the school community and create a disruption. Despite the Eighth Circuit's ruling, however, the suspensions were not actually imposed, given the lower court's injunction, which allowed the students to graduate prior to the appellate court's decision.

Reviewing these decisions and cases rendered by the Second and Ninth Circuits (Doninger v. Niehoff 2011; Wynar v. Douglas County School District 2013) may be instructive to school personnel. Possibly, school authorities could argue that if a student's off-campus expression can reasonably be expected to reach the school and be harmful toward members of the school community, Tinker's exceptions to constitutional protection should be applied. Doing so would still leave substantial protection for student expression, as the off-campus expression would have to reach the high bar of posing a school disruption or interfering with others' rights.

Actually, of the six federal circuit circuits addressing student off-campus internet expression, only the Third Circuit has upheld the students who challenged disciplinary action for their off-campus posts (J.S. v. Blue Mountain School District 2011; Layshock v. Hermitage School District 2011; Mahanoy 2020). It is disappointing that the Supreme Court's recent Mahanoy decision did not shed any light on whether these other circuit rulings were correctly decided. The Court simply held that B.L.'s weekend Snapchat post was an example of protected off-campus expression, and it did not offer illustrations of student speech initiated away from school that could be curtailed and be the basis for disciplinary action.

In the absence of clear Supreme Court guidance, if public schools discipline students for cyberbullying and other hurtful expression initiated off campus, it is unlikely that the school or its personnel would be held liable for damages for abridging clearly established rights even if the student speakers ultimately prevailed in establishing that their speech was protected by the First Amendment. Given the vague aspects of the Mahanoy decision and the differing appellate rulings, it would be hard to argue that the law is clearly established in this arena.

The Supreme Court in Mahanoy also avoided addressing the Third Circuit's declaration that B.L. did not waive her First Amendment rights by participating in an extracurricular activity, so some uncertainty remains as to the Supreme Court's position regarding how penalties attached to extracurricular teams may differ from those imposed on school attendance. Most school districts nationally have given coaches significant discretion to suspend team members for expression that does not appropriately represent the school or jeopardizes team morale (see National School Boards Association 2021).

In several lower court decisions, courts have recognized that extracurricular participation is a privilege (unlike the state-created right to attend school) and that conditions can be placed on such participation that could not be placed on school attendance. For example, in an Eighth Circuit case, a student was cut from the team for being insubordinate, and the 
appeals court upheld the action to maintain team unity and a team environment conducive to learning sportsmanship (Wildman v. Marshalltown 2001). The court emphasized that the student's class attendance was not affected by the disciplinary action. Additionally, in Lowery v. Euverard (2007), the Sixth Circuit upheld the public school's dismissal of players from the football team for circulating a petition to fire the coach; again, the court emphasized that their educational program was not impacted. Also, the Second Circuit in Doninger v. Niehoff (2011) recognized that the student's discipline for profane criticism of school personnel extended only to her role as a student government representative and not to school attendance. Upholding her removal as a candidate for class secretary, the court concluded that her posts were disruptive to the functioning of student government. From these decisions, one might assume that school authorities can still attach conditions to extracurricular participation that could not be attached to school attendance, as long as students are fully aware of the conditions when they agree to participate.

In a Utah case with facts very similar to Mahanoy, the federal district court upheld a cheerleader's dismissal from the squad for her profane post on social media that violated the squad's rules, which she had agreed to follow (Johnson v. Cache County School District 2018). In contrast, the Third Circuit in Mahanoy concluded that B.L. did not knowingly waive her off-campus expression rights by regulations she and her parents signed. As noted, the school rules B.L. signed specified that she would not share "negative information" about the school on the internet, and the appeals court concluded that her venting on Snapchat was not sharing "information" (Mahanoy 2020, p. 193). Despite the number of lower court decisions, the Supreme Court did not take the opportunity in its Mahanoy decision to clarify the status of extracurricular participation as a privilege that can be withheld.

\subsection{Suggestions for School Personnel}

There are no signs of social media use dissipating and substantial evidence exists of an increase in the harmful effects of cyberbullying, including teen suicides (see Cook 2021; Mendez-Baldwin et al. 2015). Thus, school personnel and policy makers need to redouble their efforts to educate students, parents, and other community members about ethical social media use in hopes of preventing hurtful expression and avoiding disciplinary action against students after the harm has been done. Since research indicates that youth who have close bonds to family members and peers are not as likely to be involved in cyberbullying (Cook 2021), efforts to increase student connectedness in positive ways can be helpful in reducing hurtful online expression. Students also need to understand that what they post, which appears fleeting, can easily become permanent. Even platforms where the messages are designed to disappear can be preserved by taking screen-shots that can be shared widely.

Hosting student assemblies that focus on appropriate internet use, involving student governments in establishing expression standards, using peer mentoring to curb the prevalence of harmful expression, and other strategies can be employed to increase awareness among students and their families regarding the potential emotional and psychological harm that internet postings can pose. Encouraging student leaders to model positive uses of technology can debunk the notion that cyberbullying is acceptable. Most students actually hate cyberbullying, so complimenting and celebrating kindness and compassion can alter student conduct (Hinduja and Patchin 2018). The goal should be a schoolwide norm that hurtful student expression is viewed with disdain. Involving student opinion leaders is essential, as peer groups can be powerful in changing negative norms among students. Many resources are available from the United States Government (n.d.) to encourage peers to think carefully before posting hateful and harmful items online.

Educational efforts should not focus only on the perpetrators and victims. Bystanders need to understand their responsibility to report bullying behavior that they witness on the internet or in person. If bystanders do nothing, they are quietly endorsing the hurtful behavior (Hinduja and Patchin 2014). Studies show that bystanders are far more likely to 
intervene to report cyberbullying if they can be assured that they are doing so anonymously (Cook 2021).

Prevention is always preferable to punitive actions, but disciplinary action against cyberbullies may be necessary at times. School boards should carefully articulate what expression, both on-campus and off, is considered harassment, bullying, and/or threatening. Such definitions should be known to students and their parents to ensure that any disciplinary action for their expression does not come as a surprise. It is optimal to include students and parents in designing internet use policies, the school disciplinary code, and regulations for extracurricular participation that perhaps attach specific conditions to team membership. Regulations for extracurricular participation should clearly specify when the rules apply to off-campus behavior (e.g., during competitions, throughout the season) so that students signing the provisions know exactly what they are agreeing to as a condition of the privilege of representing the school. The more specificity in school standards, the more likely school actions will be upheld if challenged in court. Additionally, the more involvement among students and parents in designing the regulations, the more likely the rules will be followed. Schools also need to establish various channels for victims and bystanders to report cyberbullying (and bullying in general) that protect the identities of the victims and witnesses.

\section{Conclusion}

For better or worse, wireless internet access, smart phones, tablet computers, social networking services like Facebook, and stream-of-consciousness communications via Twitter give an omnipresence to speech that makes any effort to trace First Amendment boundaries along the physical boundaries of a school campus a recipe for serious problems in our schools (Layshock v. Hermitage School District 2011, pp. 220-21 [Jordan, J., concurring]).

The lines between on-campus and off-campus expression certainly have become blurred since the internet is an increasingly important form of communication. The "porous" barrier "between on-campus and off-campus speech ... has very significant implications for how Tinker should apply" (Milhiser 2021, p. 3). It is difficult to justify treating student expression differently if the student clicks "send" or "post" in the school parking lot or two inches off school grounds. Moreover, the posts may be viewed by classmates on their phones at school. Sometimes it is not even possible to ascertain where or by whom the controversial message is posted.

Unfortunately, the Supreme Court's Mahanoy decision did not provide sufficient guidance for students and school personnel who are operating in a digital world. If the Court had ruled that Tinker applies to in-school and off-campus expression alike, students still would have substantial protection for anything they say that does not threaten a disruption of the school or interfere with others' rights. However, the Court did not do this and instead left ambiguity as to when students can be disciplined for speech initiated off campus. The most positive route for school personnel is to implement strategies to curtail hateful and hurtful student expression before it takes place, thus avoiding pain to victims and punishment of perpetrators. Education is our greatest resource to combat the escalating cyberbullying that is plaguing American youth.

Funding: This research received no external funding.

Institutional Review Board Statement: Not applicable.

Informed Consent Statement: Not applicable.

Data Availability Statement: Not applicable.

Conflicts of Interest: The author declares no conflict of interest. 


\section{References}

\section{Cases and Laws}

Americans with Disabilities Act of 1990, Title II. 42 U.S.C. $§ 12132$ et seq.

Bell v. Itawamba County School District, 799 F.3d 379 (5th Cir. 2015).

Bethel School District v. Fraser, 478 U.S. 675 (1986).

Civil Rights Act of 1964, Title VI. 42 U.S.C. §2000d et seq.

Davis v. Monroe County Board of Education, 526 U.S. 629 (1999).

D.J.M. v. Hannibal Public School District, 647 F.3d 754 (8th Cir. 2011).

Doe v. Dardanelle School District, 928 F.3d 722 (8th Cir. 2019).

Doe v. Hopkinton Public Schools, 490 F. Supp. 3d 448 (D. Mass. 2020).

Doe v. Pawtucket School Department, 969 F.3d 1 (1st Cir. 2020).

Doninger v. Niehoff, 642 F.3d 334 (2d Cir. 2011).

Education Amendments of 1972, Title IX. 20 U.S.C. \$1681-\$1688.

Florida v. Cowart, 301 So.3d 332 (Fla. App. 5 Dist. 2020).

Gebser v. Lago Vista Independent School District, 524 U.S. 274 (1998).

Hazelwood School District v. Kuhlmeier, 484 U.S. 260 (1988).

In Re A.G., 272 Cal. Rptr. 3d 602 (Cal. App. 2 Dist. 2020).

J.S. ex rel. Snyder v. Blue Mountain School District, 650 F.3d 915 (3d Cir. 2011).

J.S. v. Bethlehem Area School District, 794 A.2d 936 (Pa. Commw. Ct. 2002).

J.S. v. Manheim Township Sch. Dist., 231 A.3d 1044 (Pa. Commw. 2020).

Johnson v. Cache County School District, 323 F. Supp. 3d 1301 (D. Utah 2018).

Kowalski v. Berkeley County Schools, 652 F.3d 565 (4th Cir. 2011).

L.Q. v. Toms River Regional Schools Board of Education, 886 A.2d 1090 (N.J. Sup. Ct. 2005).

LaVine v. Blaine School district, 257 F.3d 981 (9th Cir. 2001).

Layshock v. Hermitage School District, 650 F.3d 205 (3d Cir. 2011) (en banc).

Lowery v. Euverard, 497 F.3d 584 (6th Cir. 2007).

Mahanoy Area School District v. B.L., 964 F.3d 170 (3d Cir. 2020), aff'd, 141 S. Ct. 2038 (2021).

Massachusetts General Laws, chapter $71 \S \S 37 \mathrm{O}(2020)$.

Morse v. Frederick, 551 U.S. 393 (2007).

New York Education Law $\S 10$ (2020).

New York Education Law § 11[8] (2020).

Pennsylvania Statutes §13-1303.1-A (2020).

People of Colorado In the Interest of Respondent R.D., 464 P.3d 717 (Colo. 2020).

People v. Marquan M., 19 N.E.3d 480 (N.Y. 2014).

S.J.W. ex rel. Wilson v. Lee's Summit R-7 School District, 696 F.3d 771 (8th Cir. 2012).

Tinker v. Des Moines Independent School District, 393 U.S. 503 (1969).

Virginia v. Black, 538 U.S. 343 (2003).

United States v. Dinwiddie, 76 F.3d 913.925 (8th Cir. 1996).

Wildman v. Marshalltown, 249 F.3d 768 (8th Cir. 2001).

Wisniewski v. Board of Education, 494 F.3d 34 (2d Cir. 2007).

Wynar v. Douglas County School District, 728 F.3d 1062 (9th Cir. 2013).

Zeno v. Pine Plains Central School District, 702 F.3d 655 (2d Cir. 2012).

\section{Other Sourses}

Anderson, Monica. 2018. A Majority of Teens Have Experienced Some Form of Cyberbullying. Cyberbullying Research Center, September 27, Available online: https://www.pewresearch.org/internet/wp-content/uploads/sites/9/2018/09/PI_2018.09.27_teens-andcyberbullying_FINAL.pdf (accessed on 12 July 2021).

Auxier, Brooke, and Monica Anderson. 2021. Social Media Use in 2021. Washington, DC: Pew Research Center, April 7, Available online: https://www.pewresearch.org/internet/wp-content/uploads/sites/9/2021/04/PI_2021.04.07_Social-Media-Use_ FINAL.pdf (accessed on 12 July 2021).

Bauman, Sheri, and Matthew L. Newman. 2013. Testing Assumptions about Cyberbullying: Perceived Distress Associated with Acts of Conventional and Cyberbullying. Psychology of Violence 3: 27-38. [CrossRef]

Chaffey, Dave. 2021. Global Social Media Research Summary 2021. Smart Insights 11: 1-10.

Cook, Sam. 2021. Cyberbullying Facts and Statistics for 2018-2021. Comparitech 31: 1-22.

Council of School Attorneys. 2021. Suit Claims California District Failed to Prevent Male Student's Cyberbullying of Female Student in Middle and High School. July 22. Available online: https:/ / community.nsba.org/cosa/blogs/thomas-burns/2021/07/22/suitclaims-california-district-failed-to-prevent?_cldee=bWFydGhhLm1jY2FydGh5QGxtdS51ZHU\%3d\&recipientid=contact-8079 838c6c4f473cb3f90c575827e290-5f67bbf41ebf428b8322c7d6780d973b\&esid=e5b11d71-dbee-47d6-a338-36d8be542a6c (accessed on 23 July 2021). 
Dhir, Sunila. 2016. Effect of Social Sites on Adolescent. International Research Journal of Management Sociology E Humanity 7: 267-71.

Ehmke, Rachel. 2020. How Using Social Media Affects Teenagers. New York: Childmind Institute, June 15, Available online: https: / / childmind.org/article/how-using-social-media-affects-teenagers/ (accessed on 16 June 2021).

Goodno, Naomi Harlin. 2011. How Public Schools Can Constitutionally Halt Cyberbullying. Wake Forest Law Review 46: 641-700.

Hess, Rick. 2021. Social Media's Like Tossing a Tween the Keys to a Harley. Education Week. July 28. Available online: https:/ / www.edweek.org/technology/opinion-social-medias-like-tossing-a-tween-the-keys-to-aharley/2021/07? utm_ source=nl\&utm_medium =eml\&utm_campaign=eu\&M=62200378\&U=1157887\&UUID=832ff56d606428dc86808013e47895a1 (accessed on 29 July 2021).

Hinduja, Sameer. 2021. Will New Censorship Bills Increase Cyberbullying on Social Media? Cyberbullying Research Center: Available online: https: / cyberbullying.org/will-new-censorship-bills-increase-cyberbullying-on-social-media (accessed on 26 July 2021).

Hinduja, Sameer, and Justin W. Patchin. 2013. Social Influences on Cyberbullying Behaviors among Middle and High School Students. Journal of Youth Adolescence 42: 711-22. [CrossRef] [PubMed]

Hinduja, Sameer, and Justin W. Patchin. 2014. Cyberbullying: Identification, Prevention, and Response. Cyberbullying Research Center: Available online: https:/ / cyberbullying.org/Cyberbullying-Identification-Prevention-Response.pdf (accessed on 24 June 2021).

Hinduja, Sameer, and Justin W. Patchin. 2018. Developing a Positive School Climate to Prevent Bullying and Cyberbullying. Cyberbullying Research Center: Available online: https:/ / cyberbullying.org/developing-a-positive-school-climate-to-prevent-bullying-andcyberbullying (accessed on 18 June 2021).

Holden, Benjamin A. 2018. Tinker Meets the Cyberbully: A Federal Circuit Conflict Round-up and Proposed New Standard for Off-Campus Expression. Fordham Intellectual Property, Media and Entertainment Law Journal 28: 233-99.

Koo, Hyojin. 2007. A Time Line of the Evolution of School Bullying in Differing Social Contexts. Asia Pacific Education Review 8: 107-16. [CrossRef]

Kosciw, Joseph G., Caitlin M. Clark, Nhan L. Truong, and Adrian D. Zongrone. 2020. The 2019 National School Climate Survey. New York: GLSEN.

McCarthy, Martha. 2021. The Fate of Off-Campus Student Expression: Mahanoy Area School District v. B.L. Education Law Reporter 378: 439-55.

McCarthy, Martha, Suzanne Eckes, and Janet Decker. 2019. Legal Rights of School Leaders, Teachers, and Students. New York: Pearson.

Mendez-Baldwin, Martha, Krista Cirillo, Matthew Ferrigno, and Victoria Argento. 2015. Cyber Bullying Among Teens. Journal of Bullying E Social Aggression 1: 1-8. Available online: http:/ / sites.tamuc.edu/bullyingjournal/article/cyber-bullying-amongteens / (accessed on 24 June 2021).

Milhiser, Ian. 2021. The Supreme Court's 'Cursing Cheerleader' Case Is its Biggest Student Free Speech Case in 14 Years. Vox. June 23. Available online: https:/ / www.vox.com/2021/6/23/22547040/supreme-court-cursing-cheerleader-stephen-breyer-freespeech-mahanoy-bl-brandi-levy (accessed on 8 July 2021).

Mohsin, Maryam. 2021. 10 Social Media Statistics. Oberlo. April 5. Available online: https://www.oberlo.com/blog/social-mediamarketing-statistics (accessed on 24 June 2021).

National School Boards Association. 2021. Amici Curiae Brief to the Supreme Court in Support of Petitioners in Mahanoy Area Sch. Dist. v. B.L. No. 20-255. SCOTUSblog. March 1. Available online: https:/ /www.scotusblog.com/case-files/cases/mahanoy-areaschool-district-v-b-1/?ct=t(EMAIL_CAMPAIGN_2_5_2021_COPY_01) (accessed on 6 July 2021).

Paradigm Treatment. 2018. How to Stop Cyberbullying among Teens. Paradigm Treatment. October 16. Available online: https: / / paradigmtreatment.com/stop-cyberbullying-among-teens / (accessed on 22 June 2021).

Reigeluth, Christopher, and Michael E. Addis. 2016. Adolescent Boys' Experiences with Policing of Masculinity: Forms, Functions and Consequences. Psychology of Men \& Masculinity 17: 74-83.

Robinson, Ryan. 2021. The 7 Top Social Media Sites You Need to Care About in 2020. Adobe Spark. Available online: https: / / www.adobe.com/express/learn/blog/top-social-media-sites (accessed on 26 July 2021).

Statista. 2021a. Daily Time Spent on Social Networking by Internet Users Worldwide from 2012 to 2020. June 30. Available online: https:/ / www.statista.com/statistics/433871/daily-social-media-usage-worldwide/ (accessed on 6 July 2021).

Statista. 2021b. Most Popular Mobile Social Networking Apps in the U.S. as of September 2019, by Monthly Users. July 6. Available online: https: / / www.statista.com/statistics/248074/most-popular-us-social-networking-apps-ranked-by-audience/ (accessed on 8 July 2021).

Tsilimparis, John. 2019. Cyberbullying: The Psychological Effects on Teens. Psych Central 17: 1-3. Available online: https:// psychcentral.com/blog/cyberbullying-the-psychological-effects-on-teens\#1 (accessed on 23 June 2021).

United States Department of Education, Office for Civil Rights. 2014. Dear Colleague Letter, October 21. Available online: https: // / www2.ed.gov/about/offices/list/ocr/letters/colleague-bullying-201410.pdf (accessed on 20 June 2021).

United States Department of Health and Human Services. 2019. Key Components in State Anti-Bullying Laws, Policies, and Regulations. January 7. Available online: https:/ / www /stp[bi;;uomg/gpv/resources/laws/key--components (accessed on 22 June 2021).

United States Government. n.d. Prevention: Learn How to Identify Bullying and Stand Up to it Safely. Available online: https: / / www.stopbullying.gov/resources/get-help-now (accessed on 26 July 2021). 